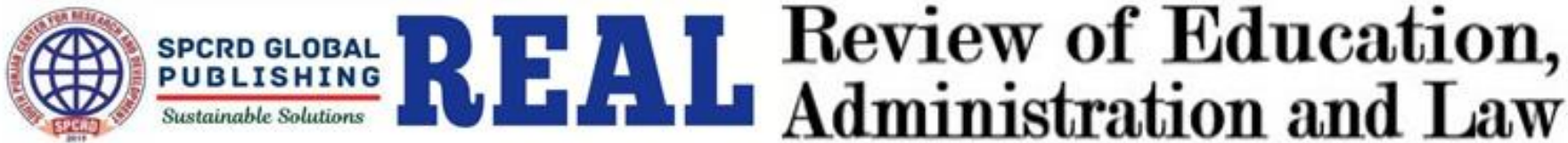 Journal homepage: http://real.spcrd.org ISSN (Print): 2708-1788
}

\section{Islamic Finance and Economic Growth Nexus: An Econometric Analysis}

\author{
Kashif Raza $^{\text {a, }}$ Rashid Ahmad b, Muhammad Abdul Rehman Shah c, Muhammad Umar d \\ ${ }^{a}$ Lecturer, Department of Economics, The Islamia University of Bahawalpur, Pakistan, Bahawalnagar Campus, \\ kashif.raza@iub.edu.pk \\ ${ }^{\mathrm{b}}$ Assistant professor, School of Economics, Bahaudin Zakariya University, Multan, Pakistan: Rashidahmad@bzu.edu.pk \\ ${ }^{c}$ University of Engineering and Technology, Taxila, Pakistan \\ ${ }^{\mathrm{d}}$ MPhil Scholar, School of Economics, Bahaudin Zakariya University, Multan: mailumarramzan@gmail.com \\ Corresponding author's email address: Rashidahmad@bzu.edu.pk
}

\begin{tabular}{|c|c|}
\hline ART & \\
\hline $\begin{array}{l}\text { Histo } \\
\text { Accep } \\
\text { Avail }\end{array}$ & \multirow{4}{*}{$\begin{array}{l}\text { Researchers have written chain of research papers about the dynamics } \\
\text { of financial development and economic growth. The financial capital } \\
\text { plays a productive role when it delivers to economic agents who are } \\
\text { facing shortage or excess of funds. This study explores the linkages } \\
\text { among Islamic financing and economic growth for Pakistan, by using } \\
\text { annual time series data from 2005-2018. Islamic banks' financing funds } \\
\text { used as a proxy of Islamic financing, Gross Domestic Product (GDP), } \\
\text { Gross Fixed Capital Formation (GFCF), labor force (LF),Broad money(M) } \\
\text { and Trade openness (TO) to presents real sector of an economy. For the } \\
\text { exploration, the unit root test, Ordinary least square technique and } \\
\text { Granger causality test are applied. The results validate a substantial } \\
\text { causal relationship of Islamic financing and GDP, which supports the } \\
\text { Schumpeter's supply-leading view. The results indicate that Islamic } \\
\text { finance contributed towards economic growth. }\end{array}$} \\
\hline $\begin{array}{l}\text { king financing, } \\
\text { Gross fixed } \\
\text { zation, Economic }\end{array}$ & \\
\hline $\begin{array}{l}\text { JEL C } \\
G 21,\end{array}$ & \\
\hline & \\
\hline & \\
\hline
\end{tabular}

\section{Introduction}

The impact In the literature of development economics, economists have written chain of research papers about the dynamics of financial development and economic growth. The financial institutions play important 1 role if it is able to provide finance to economic agents who are facing shortage or excess of funds. When the financial sector is more advanced, more physical capital can be accumulated and distributed which can accelerate economic growth with optimal level.

Nalan(2018) has shown much attention to Islamic financing and its impact on economic growth. Its research concluded that Islamic banking funds along with innovation clearly effect on economic growth.

Stolbov (2012) conducts an empirical study to examine the effect of Islamic financing system on 
economic growth and determines that at the same moment the influence of finances on economic growth doesn't capture any uniformity in trend behavior but meanwhile its depends on the level of growth of an economic system, structure of financial methods, legal system and the overall quality of organizations, So many imminent issues and promising boulevards for upcoming research.

Global markets faced confusion in a stir of the credit crunch and ensuing crisis in banking sector, it is the time to observe the evidences of marginal banking model which assumes different approaches about risk and finance, which is based on the philosophies of Sharia as alternate banking.

Islamic banking developed extensively in a last few years due to the recent financial shocks and instability, which will run a good prospect in this regard. Islamic banking and finance is the transparent growing sector in the world for development. Young's World Islamic Banking Competitiveness Report 2013, more than 400 Islamic financing institutions working in more than 80 countries. (Tabash \& Dhankar, 2014).

The development and stability of Islamic financial industry will benefit Muslim countries particularly and the rest of world generally, I n terms of economic development, poverty reduction, business opportunities, trade balances, capital formation, financial inclusion, and circulation of conservative wealth. Mohieden, Iqbal, Rostom, and Fu (2011) examine that Islamic banks contribution towards real economic growth.

Nations of Muslim communities that reject to pledge their capital in Non-Islamic banks would indulge in declining rate in, scarcity of loanable funds for investment purpose. Empirical researches show that the less proportion of Muslims community used conventional relatively non-Muslims, although it is hard to judge the percentage of responsiveness to spoil of investment. However, the democratic objectives of Islam not realized now a days due to fund transfer to poor people. For instance, see Furqani \& Mulyany (2009), Majid\& Kassim (2010), Abduh \& Omar (2012), Manap, Abduhb \& Omar (2012), Kusuma \& Muqorobin (2014), and Tabash \& Dhankar (2014). To fill gap in research, this study will try to study the link between Islamic finance and GDP growth, and their causal path crosswise the nations.

Figure 01: Growth in Islamic Banking (2005-2018)

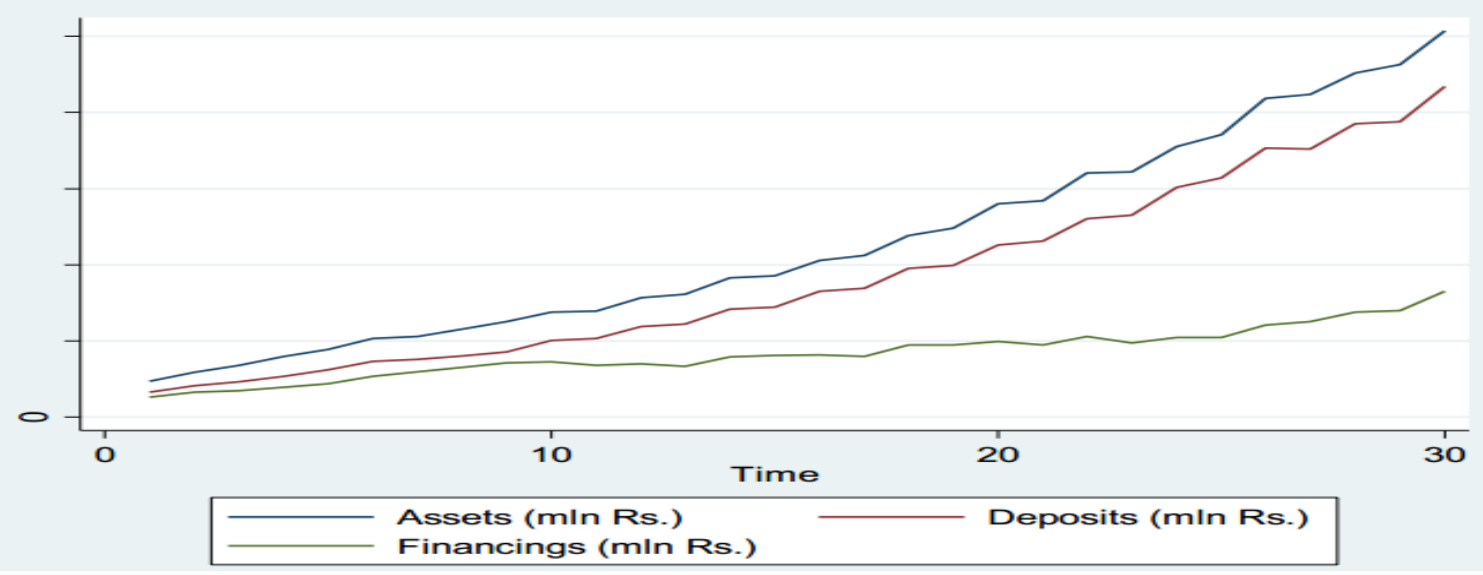

(Source: SBP Islamic Banking Bulletin, Various Issues)

Figure 01 displays the trend of returns in Islamic banking from 2005 to 2018, trend lines shows, equity, assets and return on deposits respectively. Initially it seems that few banks took time to stable. 
This study intends to discover the connection between Islamic funding and economic growth. It will develop confidence of investors and policy makers to support Islamic finance for sustained growth in Pakistan. It will appear as trend setter paper for researchers to consume their efforts in this avenue.

Table 01: Data Trend in Variables

\begin{tabular}{|l|l|l|l|l|l|l|}
\hline & $\begin{array}{l}\text { GDP } \\
\text { Million } \\
\text { Years }\end{array}$ & $\begin{array}{l}\text { GFCF } \\
\text { Million } \\
\text { Rs. }\end{array}$ & $\begin{array}{l}\text { Broad } \\
\text { Money } \\
\text { Million Rs. }\end{array}$ & $\begin{array}{l}\text { Trade } \\
\text { openness } \\
\text { Ratio }\end{array}$ & $\begin{array}{l}\text { Labor } \\
\text { force } \\
\text { Million } \\
\text { Rs. }\end{array}$ & $\begin{array}{l}\text { IB } \\
\text { financing } \\
\text { Million } \\
\text { Rs. }\end{array}$ \\
\hline $\mathbf{2 0 0 5}$ & 7738134 & 1215075 & 3182515 & 0.32932 & 46.82 & 81,463 \\
\hline $\mathbf{2 0 0 6}$ & 8216160 & 1456889 & 4631578 & 0.35681 & 50.5 & 114,965 \\
\hline $\mathbf{2 0 0 7}$ & 8613232 & 1491796 & 5439249 & 0.33403 & 50.78 & 177,475 \\
\hline $\mathbf{2 0 0 8}$ & 8759778 & 1560186 & 5794143 & 0.33368 & 52.23 & 269,087 \\
\hline $\mathbf{2 0 0 9}$ & 9007825 & 1482823 & 6814495 & 0.28855 & 55.76 & 299,295 \\
\hline $\mathbf{2 0 1 0}$ & 9152553 & 1374205 & 7807082 & 0.30983 & 57.22 & 356,545 \\
\hline $\mathbf{2 0 1 1}$ & 9404102 & 1268315 & 8790979 & 0.30451 & 58.41 & 404,758 \\
\hline $\mathbf{2 0 1 2}$ & 9733907 & 1299089 & 10306617 & 0.26934 & 59.33 & 450,634 \\
\hline $\mathbf{2 0 1 3}$ & 10159011 & 1332648 & 11676558 & 0.27542 & 60.35 & 676,570 \\
\hline $\mathbf{2 0 1 4}$ & 10640381 & 1388839 & 13028161 & 0.26139 & 60.09 & 881,228 \\
\hline $\mathbf{2 0 1 5}$ & 11229656 & 1503731 & 14637380 & 0.24326 & 63.06 & $1,181,853$ \\
\hline $\mathbf{2 0 1 6}$ & 11682893 & 1548606 & 15998152 & 0.239285 & 63.44 & $1,397,150$ \\
\hline $\mathbf{2 0 1 7}$ & 12179755 & 1615617.7 & 17432541 & 0.230058 & 64.533 & $1,636,982$ \\
\hline $\mathbf{2 0 1 8}$ & 12676616 & 1682629.4 & 18866930 & 0.220831 & 65.626 & $1,876,813$ \\
\hline
\end{tabular}

Source: World Development Indicators (WDI)\&SBP

The above table 01 describes the past trend of all macroeconomics variables and their relationship of GDP, especially core variable, with Islamic banks' financing, means in last decade it is clearly observed the increasing trend in both variables. And graphically also be observed as:

Figure o2: Trend in Islamic Banking (2005-2018)

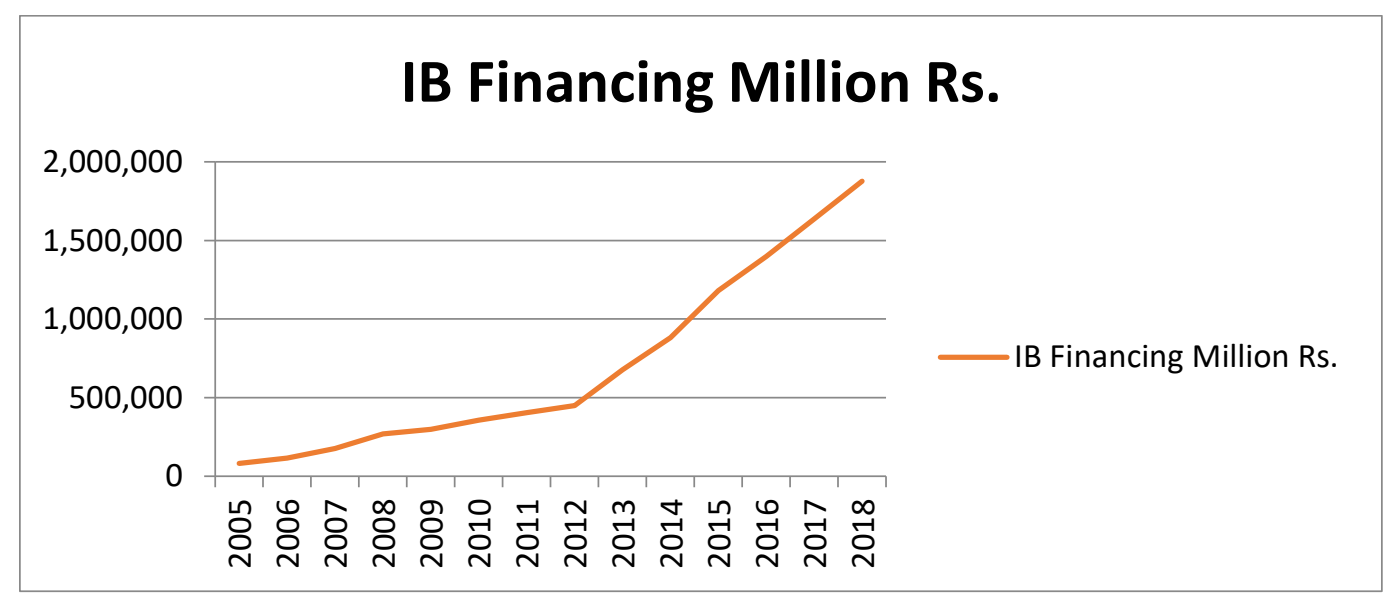

This empirical research will investigate the following hypothesis:

H1: Islamic bank's financing has significant influence on economic growth.

H2: Gross fixed capital formation has positive associated to economic growth. 
H3: Labor force has positive impact on economic growth.

$\mathrm{H}_{4}$ : Trade openness has substantial effect on economic growth.

H5: Money supply devours substantial effect on economic growth.

\section{Literature Review}

Financial stability and economic growth nexus goes back to 19th and 2oth centuries where Bagehot (1873) and Hicks (1969) claimed that financial system observed industrialization in England and more capital accumulation due to "massive works." Schumpeter (1912) stressed the significance of the banking system in economic growth and highlighted the same directional effect of financial capital on economic growth and its mechanism underlying the long run association between finance and GDP growth by identification of productive investment of funds.

McKinnon (1973) and Shaw (1973), explore that expansion of financial explorer leads to increase in output . The other fact has substantiated, for instance, King and Levine (1993) using panel data of 8o countries, document strong and positive link among financial development and per capita output.

$\mathrm{Xu}$ (2000) further illustrates that there is strong indication that financial institution strikes increase in economic growth in short run as well as long run. th, the causality directional approach is equipped to finally fall into three categories, namely (1) financial development affects economic growth (2) economic growth affects financial sector, and (3) bi-directional causality between financial development and economic growth "feedback". The former argues that the existence of financial sector would provide effectual allocation of resources to fuel the other economic sector in their growth process.

Schumpeter (1912), Demetriades \& Hussein (1996), Levine (1997) and Ahmad \& Ansari (1998), Fase \& Abma (2003) have argued that this approach is considered as the significant method in promoting economic development. The latter hypothesizes that a high economic growth may create demand for certain financial instrument and arrangements.

Robinson (1952) and Romer (1990) explained that well-built financial system could ratify high economic extension through technological changes, along with innovations and it will attract higher demand on the financial instrument. Since financial system is actively responsive on such development, a higher economic performance could be attained.

Several evidences had taken place through occurrences of economic disasters such as Mexican crisis, Indonesian crisis, and current global financial crisis in USA, which describe a potential disequilibrium to real economy. Therefore, the role of financial activity cannot be excluded in developing an economic growth of a nation. This is because financial sector has a function as financial intermediaries that accumulate capital from household sector or savers to business sector, in which the capital will be used to generating real sector which will absorb available labor in a market, and also realize profit.

Stolbov (2012) debates on systems of banks and markets appear to be equally imperative: Both sectors of the financial system are positive associated with the dynamics of an economy.

Islamic funding is one of the most developing zones of the industry and has risen to distinction due to its unique features. In the context of Islamic banks which tie to closely associate with financial intermediaries, particularly into the real economy. Furqani \&Mulyany (2009),Abduh\& Omar (2012), and Tabash \& Dhankar (2014) have explored the link among Islamic banks' financing and economic growth with a limited scope in this area. 
Quarterly data study of Indonesia for duration of 2003 to 2012, Abduh\& Omar (2012) utilize an autoregressive distributed lag (ARDL) framework and to identify the causality analysis. Therefore, the government should design the all policies in regard of Islamic in order to support the economic development.

Furqani \& Mulyany (2009) estimated econometric regression models by using the quarterly data from 1997 to 2005 and concluded that the relationship between Islamic financial capital and economic growth. Which clearlyencourage Islamic financing through banks. On the other hand,Majid \&Kassim (2010) is in errand of the supply-leading opinion.

Kusuma \& Muqorobin (2014) observe the rapid progress of the Islamic banks in Indonesia and assess the stability of these banks in order to prove that they positively contribute towards the country's economic growth using the Vector Auto Regression (VAR) analysis. Tabash \&Dhankar (2014) discovers linkages in the region of Middle East about Islamic finance and economic growth nexus especially for Qatar, Bahrain, and United Arab Emirates(UAE) and appears to be a bi-directional correlation for Bahrain and Qatar using Granger causality test. The results obtained for UAE directs that a causal relationship transpires unique direction, which cares Schumpeter's supply-leading theory.

The literature highlighted a large prospective for Sharia financial goods to play an energetic role in growth in future perspective. Infrastructure development is a key to stimulus economic development. Al-Rajhi (1999) describes many opportunities with the help of Islamic banks to finance development projects in private as well as public sector with economic organizations in a world.

\section{Data and Methodology}

The question arises over here according to recent literature that what drives changes in economic growth? Is it only Islamic banks' financing? Obviously no, physical capital and others factors also play vital role in economic growth. As standard Cobb-Douglas production function "Yt = AL $\alpha \mathrm{K} \beta$ “, that is significant to economic growth. "A" is generally considered as total factor productivity, " $L$ " is the quantity of labor and Gross fixed capital formation (GFCF) represents the Quantity of Capital.

\subsection{Econometric Methodology}

This study used Granger causality test to investigate correlation between Islamic banks' financing and economic growth and ordinary least square method for regression analysis. But checking the stationary of the data series of relevant macro-economic factors is the first step before regression analysis.

\subsection{Unit Root Test}

This test is used to check the stationary of the data. If probability distribution of data remains unchanged as time go on then data can considered as stationary.

\subsection{Granger causality Technique}

The aim here is to probe the effect of Islamic financing' on the process of Economic growth in Pakistan. For this purpose general methodology is written as: The granger causality test for variables, involves as initially estimate the following VAR model as: 


$$
\begin{array}{r}
Z_{t}=\beta_{1}+\sum_{i=1}^{m} \beta i X_{t}+\sum_{j=1}^{m} \gamma i Z_{t-j}+\mu_{1 t} \\
Z_{t}=\beta_{2}+\sum_{i=1}^{m} \varnothing i X_{t}+\sum_{j=1}^{m} \delta i Z_{t-j}+\mu_{2 t} \ldots \ldots \ldots
\end{array}
$$

Where it is supposed that both $\mu_{\mathrm{Zt}}$ and $\mu_{\mathrm{Xt}}$ is not correlated with error term.

\subsection{Ordinary least square method (OLS)}

Ordinary least square technique used to examine nature and form of relationships among two or more variables. OLS is a method of estimation which has some assumptions and also follows these assumptions while appalled this method these assumption eight in number. OLS also satisfied the property of BLUE which means Best linear Unbiased Estimation among linear regression model these called properties of the OLS estimators.

$$
\mathbf{Y}_{\mathbf{t}}=\mathbf{a}+\boldsymbol{\beta} \mathbf{X}_{\mathbf{t}}+\mathbf{u}_{\mathbf{t}}
$$

This gives us the following relationship, which is a fitted straight line with intercept $\hat{\mathrm{a}} \cdot$ and slope $\hat{\beta}$.

$$
\hat{\mathbf{Y}} \mathbf{t}=\hat{\mathbf{a}}^{\cdot}+{ }_{\boldsymbol{\beta}} \mathbf{X t} \mathbf{. .}
$$

\subsection{Model Specification}

The pragmatic analysis of study based on production function, as $Y=A L \alpha K 1-\alpha$ that is also mentioned earlier. The purpose of the study is to explore the association between Islamic banks' financing and economic growth.

$$
\mathrm{Y}=\mathrm{AL} \alpha \mathrm{K} \beta \mathrm{IF \varepsilon T} \gamma \mathrm{M} \delta \mathrm{Uie}
$$

Economic Growth= f (Labor force, Physical capital, Islamic financing, trade openness, Broad money)

But the basic regression takes the following form:

$$
\ln Y=\beta o+\beta_{1} \ln \mathrm{IBF}_{+} \beta_{2} \ln \mathrm{M}_{+} \beta_{3} \ln G F C F+\beta_{4} \ln L F+\beta_{5} \ln \mathrm{T}+\mathrm{U}_{\mathrm{t}} \ldots .(5)
$$

Where, Y represents real GDP as a proxy of economic growth. Islamic banks' financing (IBF), money supply (M), Gross fixed capital formation (GFCF), Labor force (LF), and Trade openness (T) are there mentioned in model. 
Table o2: Description of Variables:

\begin{tabular}{|c|c|c|c|}
\hline Variable & Data range & Unit of measurement & Data source \\
\hline Real GDP & $2005-2018$ & Million rupees & WDI \\
\hline $\begin{array}{l}\text { Islamic banks' } \\
\text { financing (IBF) }\end{array}$ & $2005-2018$ & Million rupees & SBP \\
\hline $\begin{array}{l}\text { Gross fixed capital } \\
\text { formation(GFCF) }\end{array}$ & $2005-2018$ & Million rupees & WDI \\
\hline Broad Money (BM) & $2005-2018$ & Million rupees & WDI \\
\hline Labor Force (LF) & $2005-2018$ & Million & WDI \\
\hline Trade openness (TO) & $2005-2018$ & $\frac{\text { IMPORTS + EXPORTS }}{\text { GDP }}$ & WDI \\
\hline
\end{tabular}

\section{Results and Discussion}

This section explained the all estimation results along with discussion and its relevancy with real sector. Before estimating regression model, Descriptive analysis is discussed in detail, Unit root test, Ordinary least square, and at the end granger causality test 'results are to be discussed

\subsection{Descriptive analysis:}

Table o3: Descriptive statistics

\begin{tabular}{|l|l|l|l|l|l|l|}
\hline & \multicolumn{1}{|c|}{ GDP } & \multicolumn{1}{|c|}{ BM } & \multicolumn{1}{|c|}{ GFCF } & \multicolumn{1}{|c|}{ IBF } & \multicolumn{1}{|c|}{ LF } & \multicolumn{1}{|c|}{ TO Ratio } \\
\hline Mean & 9332249 & 8373524 & 1397600. & 444898.2 & 55.86889 & 0.300565 \\
\hline Median & 9152553 & 7807083 & 1388839. & 356545.9 & 57.22000 & 0.304519 \\
\hline Maximum & 11229656 & 14637381 & 1560186. & 1181854. & 63.06778 & 0.356817 \\
\hline Minimum & 7738134. & 3182515 & 1215075. & 81463.73 & 46.82000 & 0.243264 \\
\hline Std. Dev. & 1045490. & 3669960 & 110420.2 & 340760.1 & 5.097467 & 0.035888 \\
\hline Skewness & 0.335834 & 0.320981 & -0.181413 & 1.016331 & -0.377759 & -0.044841 \\
\hline Kurtosis & 2.281354 & 1.933434 & 1.828429 & 3.018287 & 1.951221 & 1.834832 \\
\hline Jarque-Bera & 0.443479 & 0.710270 & 0.689435 & 1.893856 & 0.765758 & 0.625928 \\
\hline Probability & 0.801124 & 0.701079 & 0.708420 & 0.387931 & 0.681895 & 0.731276 \\
\hline
\end{tabular}

(Source: Authors own' calculation)

Table 02 shows the central tendency' value of all variables as GDP is 9332249 million rupees on average, Broad money is 8373524 , GFCF is 1397600 , Islamic banking' Financing is 444898.2 million 
rupees, Labor Force is 55.86889 million in numbers, Trade openness is 0.300565 million in ratio.11 observations of time series data set are used for analysis. Dispersion of thee data set is to be checked with standard deviation' values. Normality of the data distribution is observed with the help of values of kurtosis and Skewness. Skewness is a measure of asymmetry of probability distribution of a definite value arbitrary variable about its mean. Skewness can appear in the form of negatively Skewed or positively Skewed series of data, depending on whether individual observations are slanted to the left as negatively skewed and right as positively skewed data distribution. Kurtosis telling us about the degree of Peakedness or smoothness of Uni- model frequency curve. Mesokurtic showed the normality of data distribution (bell shaped data distribution).Jarque -bera test also used to observe the normal distribution.

\subsection{Unit Root Analysis}

Table 04: ADF test results:

\begin{tabular}{|l|l|l|l|}
\hline & & & \\
Variable Names & Trend & Trend and Intercept & Stationary \\
\hline Gross Domestic Product & -0.4211 & -4.1843 & \\
& $(0.7328)$ & $(0.0000)$ & $\mathrm{I}(\mathrm{o})$ \\
\hline Islamic banks' financing & -0.4953 & -3.872107 & \\
& $(0.8853)$ & $(0.0000)$ & $\mathrm{I}(\mathrm{o})$ \\
\hline Money Supply & -0.71795 & -9.4618 & \\
& $(0.8909)$ & $(0.0000)$ & $\mathrm{I}(\mathrm{o})$ \\
\hline Gross Fixed Capital Formation & -1.4234 & -8.3516 & \\
& $(0.3153)$ & $(0.0000)$ & $\mathrm{I}(\mathrm{o})$ \\
\hline Trade Openness & -0.3753 & -6.47217 & \\
& $(0.8853)$ & $(0.0000)$ & $\mathrm{I}(\mathrm{O})$ \\
\hline Labor Force & -0.3685 & -9.2304 & \\
& $(0.8449)$ & $(0.0000)$ & $\mathrm{I}(\mathrm{o})$ \\
\hline
\end{tabular}

(Source: parenthesis shows probabilistic values)

\subsection{Ordinary Least Square Method (OLS):}

Table 05: Results of OLS

\begin{tabular}{|l|l|l|l|l|l|}
\hline Variable & Coefficients & $\begin{array}{l}\text { Standard } \\
\text { Error }\end{array}$ & t-statistics & Probability & Remarks \\
\hline IB financing & 1.32 & 0.27 & 4.74 & 0.0015 & Significant \\
\hline $\begin{array}{l}\text { Broad } \\
\text { money }\end{array}$ & 0.26 & 0.26 & 0.98 & 0.0012 & Significant \\
\hline GFCF & 0.23 & -0.19 & -1.22 & 0.0911 & Significant \\
\hline Labor force & 0.40 & 0.17 & 2.32 & 0.0305 & Significant \\
\hline $\begin{array}{l}\text { Trade } \\
\text { openness }\end{array}$ & 0.17 & 0.25 & 0.67 & 0.5006 & Insignificant \\
\hline Constant & 11.55 & 2.56 & 4.50 & 0.0043 & Significant \\
\hline
\end{tabular}


These results suggested that Islamic banks' financing, broad money, GFCF, trade openness and Labour force have positive significant impact on GDP growth.

Ordinary least square' results indicated that positive association exist between Islamic banking' financing and economic growth in line with Furqani \& Mulyany (2009), Majid\& Kassim (2010), Abduh\& Omar (2012), Manap, Abduhb\& Omar (2012), Kusuma\& Muqorobin (2014), and Tabash \& Dhankar (2014). Islamic financing increases number of participants (Financial Inclusion) in financial markets because Pakistan is with major Muslim population and they are interest sensitive. Hence, Islamic investment avenues provided them opportunity to park their abundant funds. This confidence, increased overall economic growth of country as empirical results supported our hypothesis of a positive relationship between Islamic finance and economic growth.

If Broad money (money supply) increased as a result increment in general price level enhance incentive to producer in term of profit with the help of increase in production of goods and services means economic growth in an economy.

Foreign direct investment supports market expansion, decrease cost per unit of products, technological progress become a reason to attain the attention of foreign investors.so for that reason Trade openness is used as proxy variables to check the volume of the country and volume of the country is determined through imports and exports so, these indicators impose positive relationship on GDP growth. Through this way concluded that trade openness cast positive impact on economic growth.

Excess Labor force definitely enhances economic growth. Human capital is a big source to increase real goods and services in an economy in best manner. Gross Fixed Capital Formation enhanced growth activity in an economy but in developing countries because of lack of employment opportunities and having low amount for saving so, mostly investment are used in non-durable assets instead of durables assets which leads to increase the debt burden overall.

\subsection{Granger Causality Analysis}

Table o6: Causality Results

\begin{tabular}{|l|l|l|l|}
\hline Null Hypothesis: & Obs & F-Statistic & Prob. \\
\hline Broad Money does not Cause GDP & 14 & 1.02242 & 0.0079 \\
\hline GDP does not Cause Broad Money & & 3.54306 & 0.0085 \\
\hline GFCF does not Granger Cause GDP & 14 & 4.42181 & 0.0222 \\
\hline GDP does not Granger Cause GFCF & & 2.98774 & 0.1608 \\
\hline Islamic banks' financing does not Cause GDP & 14 & 3.26178 & 0.0019 \\
\hline GDP does not Cause Islamic banks' financing & & 3.70532 & 0.1229 \\
\hline Labor force does not Granger Cause GDP & 14 & 2.07992 & 0.0046 \\
\hline GDP does not Granger Cause Labor force & & 7.41911 & 0.0451 \\
\hline \hline Trade openness does not Cause GDP & 14 & 1.77166 & 0.2812 \\
\hline GDP does not Granger Cause Trade openness & & 3.95623 & 0.1128 \\
\hline
\end{tabular}


We used Engle Granger Causality test to find out relationship between different economic variables. There are a number of variables in our model, but here we used a few of to find out the causal relation, weather the causal relationship exists between variables or not. The long term connection between different variables established. The definition about Granger causality is form from different predictability. The basic concept of Engle Granger causality is too find weather one variable may or may not cause one another. Probability values of the variables are used for this purpose, then calculate the values and make the hypothesis according to the probability values of Granger causality relationships. Broad money does granger because the GDP, and GDP does granger cause the broad money according to probability value which is less than 10 percent.

According to probability value, we also reject the null hypothesis on fundamental relationship between Islamic banking' financing and GDP. Islamic banking' financing does cause GDP. Gross fixed capital formation (GFCF), Labor force (LF) also granger cause Gross domestic product (GDP) instead of Trade openness, according to probability value of results.

\subsection{Conclusion}

The results designate that development of Islamic financial institutions in Pakistan will leads to economics growth \& development. On empirical grounds, Islamic financing has emerged as the best source of financial inclusion in financial market of Pakistan where $97 \%$ Muslim population is interest sensitive. This study recommends to policy makers to increase Sharia's compliant investment opportunities for sake of high growth rate because empirical results show a positive relationship between Islamic banks' financing and economic growth. It will also play a vital role in long run for economic welfare and poverty alleviation.

\section{References}

Abdul, M. and Omar, M. (2012),"Islamic banking and economic growth: the Indonesian experience", International Journal of Islamic and Middle Eastern Finance and Management, Vol. 5, No. 1, pp. $35-47$.

Al Rajhi, Abdullah Sulaiman. (1999) “Islamic Banks: Technology and Global Challenges and Opportunities" Proceedings of the Third Harvard University Forum on Islamic Finance. Centre for Middle Eastern Studies, Harvard University, 177-178.

Bagehot, W. 1873. Lombard Street: A Description of the Money Market. Homewood, Illinois:Irwin.

Bangake, C., and Eggoh, J. (2011). "Further Evidence on Finance-Growth Causality: A Panel Data Analysis,"Economic Modeling, 35(2) 176-188.

Bashir, Abdel-Hameed M. (1999) "Monetary Policy and Economic Growth: An Islamic Perspective" Proceedings of the Third Harvard University Forum on Islamic Finance. Centre for Middle Eastern Studies, Harvard University, 13-22.

Demetriades, P.O. and Hussein, K.A., (1996). "Does financial development cause economic growth? Time series evidence, from 16 countries,” Journal of Development Economics, Vol. 51, pp. 387-411. Fase, M.M.,andAbma, R.C., (2003)."Financial environment and economic growth in selected Asian countries.”Journal of Asian Economics, 14(3), pp.11-21.

Furqani, H.,andMulyany, R. (2009).“Islamic Banking and Economic Growth: Empirical Evidence from Malaysia,"Journal of Economic Cooperation, 30(2), 59-74.

King, Robert, G.,and Levine, Ross, (1993). "Finance and Growth: Schumpeter Might Be Right," The Quarterly Journal of Economics, MIT Press, vol. 108(3), pages 717-37.

Kusuma, Dimas B. Wiranat.,Muqorobin, M. (2014), “Assessing Financial Stability on Islamic Banks and Its Contribution to Economic Growth: Empirical Evidence from Indonesia,” ISRA International 
Colloquium for Islamic Financ, (IICIF 2014), 1-32.

Levine, R. (1997), "Financial Development and Economic Growth: Views and Agenda," Journal of Economic Literature, American Economic Association, vol. 35(2), pages 688-726.

Luintel, K. B.,and Khan, M. (1999), "A quantitative reassessment of the finance-growth nexus, Evidence from a multivariate VAR," Journal of Development Economics, 6o, 381-405.

Majid, S. A., and Kassim, S. (2010), “Islamic finance and economic growth: The Malaysian experience,” In Kuala Lumpur Islamic Finance Forum, Kuala Lumpur, 2-5 August.

Manapa, Turkhan Ali Abdul., Abduhb, Muhamad., Omar, MohdAzmi., (2012), "Islamic Banking-Growth

Nexus: Evidence from Toda-Yamamoto and Bootstrap Granger Causality Test.” IIUM Institute of

Islamic Banking and Finance, Journal of Islamic Finance, Vol. 1 No. 1 (2012) 059 - 066.

McKinnon, Ronald I, (1973), “Money and Capital in Economic Development.” Washington DC:

Brookings Institution.

Mikhail Stolbov (2012). The Finance-Growth Nexus Revisited: From Origins to a Modern Theoretical Landscape. Economics Discussion Papers, No 2012-45, Kiel Institute for the World Economy Mohielden, Mahmoud, Iqbal, Zamir, Rostom, Ahmed, Fu, Xiaochen. (2011) “The Role of Islamic Finance in Enhancing Financial Inclusion in Organization of Islamic Cooperation (OIC) Countries” The World Bank Working Paper No. 5920.

Nalan (2018), Growth, Islamic Banking and Schumpeterian Vision: An Empirical Evidence from the Gulf Arab States”International Journal of Islamic Economics and Finance studies Vol (4) Issue No 1 PP 40-55

Tabash, Mosab I., and Dhankar, Raj S, (2014),The Flow of Islamic Finance and Economic Growth: an

Empirical Evidence of Middle East,"Journal of Finance and Accounting. Vol. 2, No. 1, pp. 11-19.

Robinson, Joan, (1952), “The generalization of the general theory. In The Rate of Interest and Other Essays.” London: Macmillan.

Schumpeter, Joseph A, (1911), “The Theory of Economic Development.” Cambridge Mass: Harvard University Press.

Shaw, Edward S., (1973).“Financial Deepening in Economic Development.” New York: Oxford University Press.

Stolbov, Mikhail. (2012), “The Finance-Growth Nexus Revisited: From Originsto a Modern Theoretical Landscape", http://www.economicsejournal.org/economics/discussionpapers/2012-45 $\mathrm{Xu}$, Zhenhui., (2000), “Financial development, investment, and growth.”Economic Inquiry .38: $331-44$. 